\title{
PD44 - In vitro fertilisation is positively associated with prevalence of asthma in childhood
}

\author{
George V Guibas ${ }^{1}$, George Moschonis ${ }^{2}$, Paraskevi Xepapadaki ${ }^{1}$, Eirini Roumpedaki ${ }^{1}$, Odysseas Androutsos ${ }^{2}$, \\ Yannis Manios ${ }^{2}$, Nikolaos G Papadopoulos ${ }^{1}$ \\ From 3rd Pediatric Allergy and Asthma Meeting (PAAM) \\ Athens, Greece. 17-19 October 2013
}

\section{Background}

Research on potential perinatal risk factors for asthma, has recently attracted considerable attention. Asthma could be associated with In vitro fertilization (IVF) via epigenetic modification of DNA by IVF drugs/hormones or via a genetic link of asthma with parental subfertility. Nevertheless, evidence of an asthma/IVF correlation is scarce and inconclusive. We therefore opted to explore a potential link, in a cross-sectional population-based study in preadolescent children.

\section{Methods}

Wheeze in the last 12 months (current), wheeze ever, physician-diagnosed asthma and method of conception were recorded from questionnaires filled in by the parents of 2016 Greek children aged 9-13. Perinatal data was collected from their medical records and the questionnaires; anthropometric measurements were conducted. Logistic regression models were build in the Statistical Package for Social Sciences (SPSS version 20.0), with the wheeze/asthma variables as main outcomes. A two-tailed $p$ value less that 0.05 , was considered statistically significant.

\section{Results}

IVF correlated with physician-diagnosed asthma $(\mathrm{OR}=2.69,95 \% \mathrm{CI}=1.5-4.79, \mathrm{p}=0.001)$ and ever wheeze $(\mathrm{OR}=2.01,95 \% \mathrm{CI}=1.07-3.78, \mathrm{p}=0.03)$ but not with current wheeze $(\mathrm{p}>0.05)$ in univariate unadjusted regression models. The link of IVF with asthma remained significant $(\mathrm{OR}=2.04,95 \% \mathrm{CI}=1-4.15, \mathrm{p}=0.05)$ after adjustment for a wide array of potential confounding factors (maternal prenatal smoking, gestational age, single or multiple

\footnotetext{
${ }^{1}$ Allergy Department, $2^{\text {nd }}$ Pediatric Clinic, University of Athens, Athens, Greece

Full list of author information is available at the end of the article
}

gestation, method of delivery, birth weight, gender, parity, breastfeeding, parental educational level, passive smoking at home, current BMI, family status, mother occupation, people involved in daily childcare and municipality/ county/urbanity wherein the subjects resided). However the link with ever wheeze was lost ( $p>0.05)$.

\section{Conclusions}

Conception via in vitro fertilization may predispose children to future asthma development.

\section{Authors' details}

${ }^{1}$ Allergy Department, $2^{\text {nd }}$ Pediatric Clinic, University of Athens, Athens, Greece. ${ }^{2}$ Department of Nutrition and Dietetics, Harokopio University, Athens, Greece.

Published: 28 February 2014

\section{doi:10.1186/2045-7022-4-S1-P44}

Cite this article as: Guibas et al.: PD44 - In vitro fertilisation is positively associated with prevalence of asthma in childhood. Clinical and Translational Allergy 2014 4(Suppl 1):P44.

Submit your next manuscript to BioMed Central and take full advantage of:

- Convenient online submission

- Thorough peer review

- No space constraints or color figure charges

- Immediate publication on acceptance

- Inclusion in PubMed, CAS, Scopus and Google Scholar

- Research which is freely available for redistribution

Submit your manuscript at www.biomedcentral.com/submit 